\title{
Factors associated with hospital-acquired infections among the intensive-care patients in a tertiary-care hospital in Sri Lanka and the nurses' knowledge on precautionary measures.
}

\author{
Sajini R. Tennakoon ${ }^{1}$, Sanduni Thanujika ${ }^{1}$, Tharsiga Thanigasalam ${ }^{1}$, Thilini Wickramaarachchi ${ }^{2}$, \\ Shashimali Wickramasinghe ${ }^{1}$
}

${ }^{1}$ Faculty of Medicine, Colombo, Sri Lanka

${ }^{2}$ Lady Ridgeway Hospital, Sri Lanka

\author{
Article information \\ Total number of \\ Words 1908 \\ Tables 04 \\ Authors have no conflicts of interest to \\ declare
}

Keywords: Hospital acquired infections, Intensive care units (ICUs), Ventilator associated pneumonia, Standard precautions

Date of submission: 06.02.2019

Date of acceptance: 13.12.2019

Author responsible for correspondence: Sajini Raveendra Tennakoon No 42, $2^{\text {nd }}$ Lane, Vimukthi mawatha Pelawatta, Battaramulla

Email: raveendra1102@gmail.com

https://orcid.org/0000-0003-2924-1636

DOI: http://doi.org/10.4038/cjms.v56i1.4951

\begin{abstract}
Background:

Patients in Intensive Care Units (ICUs) are at a higher risk of developing Hospital Acquired Infections (HAIs). Therefore, the health staff in ICUs should have an adequate knowledge about the precautions to be taken to minimize HAIs in ICUs.
\end{abstract}

\section{Objectives:}

The aim of this research was to assess the prevalence of HAIs and their associated factors among the patients treated in ICUs at the National Hospital of Sri Lanka (NHSL) and to access the knowledge among nursing officers on precautions taken to minimize HAIs.

\section{Methods:}

This descriptive cross-sectional study had two components. For the first component, 110 patients being treated for more than 48 hours at ICUs at NHSL were recruited by consecutive sampling. A data was extracted from hospital records. Descriptive statistics and chi square test were used to analyze the data.

The second component was conducted among 125 nursing officers working at ICUs at NHSL who were selected by convenience sampling. A self-administered questionnaire was used to assess their knowledge regarding precautions taken to minimize HAIs. Descriptive statistics were used to describe the knowledge.

\section{Results:}

The prevalence of Ventilator Associated Pneumonia (VAP), hospital acquired Urinary Tract Infections (UTIs) and cannula associated Blood Stream Infections (BSIs) were 29.3\%, 10\% and 5.5\% respectively. The duration of stay $(\mathrm{p}=0.001)$, diabetes mellitus $(\mathrm{p}=0.008)$ and long-term use of antibiotics $(\mathrm{p}=0.001)$ were significantly associated with VAP while only long-term use of antibiotics was significantly associated with hospital acquired UTIs. Among the nursing officers $46.4 \%$ had scored above $75 \%$ for the knowledge questionnaire.

\section{Conclusions and recommendations:}

Our studies showed that HAIs are prevalent in the ICUs in NHSL and the health care staffs need to improve their knowledge and take interventions to minimize these infections. 


\section{Background}

Hospital acquired infections (HAI) are defined as infections those occurring 48 hours of hospital admission, 3 days of discharge or 30 days of an operation without evidence of incubation at the time of admission to a health care setting[1]. HAIs can be respiratory tract infections, urinary tract infections, surgical site infections, line associated infections and bacteremia, hospital acquired tuberculosis, antibiotic associated diarrhoea and nosocomial viral infections etc. Predisposing factors in HAI can be classified according to patient factors, hospital environment, and medical and surgical factors. HAIs result in excess length of stay, morbidity, mortality and loss to the health care system[1].

Patients in the ICU are more susceptible to HAI because they are housed in an enclosed community and are immunocompromised by the stress and metabolic effects of the existing disease. Most of them have recently undergone anesthetic and surgical procedures and they are in need of invasive procedures both of which would interrupt their physical barrier mechanisms.

Standard precautions are the primary strategies in preventing transmission of infectious agents among patients and health care personnel. These precautions have to be carried out by all the health care workers specially by nursing officers since they are responsible for assisting invasive procedures like mechanical ventilation, intubation, central venous catheterization, tracheostomy, chest tube insertions, feeding tube insertions are carried out in the ICUs. So adequate knowledge on standard precautions and transmission-based precautions are mandatory to maintain an infection free ICU setting.

There are only few local studies conducted regarding the prevalence of HAIs in all the ICUs in NHSL. According to the study carried out by Wanigasuriya (1999) in the ICUs at the NHSL, lower respiratory tract infections occurred in $28.4 \%$, UTIs in $20.0 \%$ and infections of intravenous cannula sites in $19.2 \%$ of patients[2]. The aim of this study was to assess the prevalence of HAIs and their associated factors among the patients being treated at the ICUs at the NHSL and the knowledge among nursing officers regarding the precautions taken to minimize HAIs at ICUs at NHSL.

\section{Methods}

The study was conducted in all the Intensive Care Units (ICUs) at National Hospital, Sri Lanka
(NHSL) from $1^{\text {st }}$ of September 2016 to $1^{\text {st }}$ of October 2016. The study had two components. For the first component, 110 participants were selected from the patients who were being treated in the ICUs for more than 48 hours at the time of data collection and consecutive sampling was carried out. The data extraction form which was in English was prepared according to the Center for Disease Control and prevention (CDC) guidelines[3]. It consisted of 4 parts; general information regarding the patient and patient factors associated with HAI, common criteria to diagnose HAI, specific criteria to diagnose Ventilator associated pneumonia, Catheter associated UTI, cannula associated blood stream infections and other factors associated with HAI. The data extraction form was filled up by recruiting information from the hospital medical record of patients by investigators.

For the second component, 125 participants were selected from the nursing officers working at all the functioning ICUs. We used convenience sampling technique to sample nurses on a daily basis until the sample size was met. After obtaining the informed written consent, the selfadministered questionnaires were distributed among the nurses to complete and questionnaires were collected after 3 days.

The self-administered questionnaire which was in Sinhala, Tamil and English languages was prepared for the nursing officers to assess the knowledge regarding precautions to minimize HAIs with regard to hand hygiene, standard precautions, spill management and HAIs (VAP, Catheter associated UTI, Cannulae associated BSIs). The questionnaire was based on 'Practical guidelines for infection control in health care facilities' published by WHO in 2004[4] and another publication on knowledge and attitudes of infection prevention and control among health care students at University of Namibia [5].

Frequency distribution table was plotted to assess the prevalence of HAIs in ICUs. The associated factors were assessed by using chi square test. Factors with a $\mathrm{P}$ value of $<0.05$ were taken as statistically significant. The collected data were analyzed using SPSS version 20.

The level of knowledge among the nursing officers on standard precautions was categorized depending on the marks obtained as adequate $(\geq 75 \%)$, moderate $(50 \%-74 \%)$ and poor $(\leq 49 \%)$. Frequency distribution table was drawn to assess the knowledge among nursing officers regarding precautions taken to minimize HAIs at ICUs at NHSL. The knowledge levels of nursing officers 
for different components were assessed separately according to the scores obtained for each component.

\section{Results}

In the first part of study 110 patients being treated at ICUs in the NHSL were recruited; majority was males. The age ranged from 2 years to 81 years with a mean of 46.8 years $(\mathrm{SD}=18.9)$. Table 1 shows frequencies of Hospital Acquired Infections among the them. Significances of association between the identified factors and Ventilator Associated Pneumonia, hospital acquired Urinary Tract Infections and hospital acquired blood stream infections are shown in the table 2, 3 and 4 respectively.

Table 1. Frequency of Hospital Acquired Infections among the patients being treated at all the ICUs in the NHSL

\begin{tabular}{|lccc|}
\hline $\begin{array}{l}\text { Presence } \\
\text { of Hospital } \\
\text { Acquired } \\
\text { Infections }\end{array}$ & \multicolumn{3}{c|}{ No of patients (percentage) } \\
\cline { 2 - 4 } & VAP & $\begin{array}{c}\text { Hospital } \\
\text { Acquired } \\
\text { UTI }\end{array}$ & $\begin{array}{c}\text { Hospital } \\
\text { Acquired } \\
\text { BSI }\end{array}$ \\
\hline Positive & 24 & 11 & 6 \\
& $(29.3 \%)$ & $(10.0 \%)$ & $(5.5 \%)$ \\
Negative & 58 & 99 & 104 \\
& $(70.7 \%)$ & $(90.0 \%)$ & $(94.5 \%)$ \\
Total & 82 & 110 & 110 \\
& $(100 \%)$ & $(100 \%)$ & $(100 \%)$ \\
\hline
\end{tabular}

*VAP - Ventilator Associated Pneumonia

UTI - Urinary Tract Infections

BSI - Blood Stream Infections

The commonest hospital acquired infection in the ICUs at NHSL was VAP. There is a significant association between ventilator associated pneumonia and the duration of stay $(\mathrm{p}=0.001)$, diabetes mellitus $(\mathrm{p}=0.008)$ and long term use of antibiotics $(\mathrm{p}=0.001)$. Hospital acquired urinary tract infections were significantly associated only with the long term use of antibiotics $(\mathrm{p}=0.006)$. None of the assessed factors were significantly associated with hospital acquired blood stream infections.

The knowledge levels of nursing officers on hand hygiene, standard precautions, transmission based precautions and hospital acquired infections were assessed based on the scores obtained for the questionnaire. Response rate was $100 \%$. Among the nursing officers who participated, $46.4 \%$ had adequate knowledge, $50 \%$ moderate knowledge while $3.6 \%$ had poor knowledge. Mean score was 72.5 with a standard deviation of 12.9.
Table 2. Factors associated with Ventilator Associated Pneumonia

\begin{tabular}{|c|c|c|c|}
\hline $\begin{array}{l}\text { Associated } \\
\text { factors }\end{array}$ & $\begin{array}{c}\text { VAP } \\
\text { positive }\end{array}$ & $\begin{array}{c}\text { VAP } \\
\text { negative }\end{array}$ & $\begin{array}{c}\mathbf{p} \\
\text { value }\end{array}$ \\
\hline \multicolumn{4}{|l|}{ Age categories } \\
\hline$<35$ years & $\begin{array}{c}8 \\
(33.3 \%)\end{array}$ & $\begin{array}{c}16 \\
(66.7 \%)\end{array}$ & 0.870 \\
\hline 35-64 years & $\begin{array}{c}12 \\
(27.28 \%)\end{array}$ & $\begin{array}{c}32 \\
(72.72 \%)\end{array}$ & \\
\hline$\geq 65$ years & $\begin{array}{c}4 \\
(28.57 \%)\end{array}$ & $\begin{array}{c}10 \\
(71.42 \%)\end{array}$ & \\
\hline \multicolumn{4}{|l|}{$\begin{array}{l}\text { Duration of } \\
\text { stay in the } \\
\text { ICU }\end{array}$} \\
\hline 2-7 days & $\begin{array}{c}2 \\
(9.75 \%)\end{array}$ & $\begin{array}{c}37 \\
(90.24 \%)\end{array}$ & 0.001 \\
\hline 8-14 days & $\begin{array}{c}10 \\
(43.47 \%)\end{array}$ & $\begin{array}{c}13 \\
(56.52 \%)\end{array}$ & \\
\hline 15-30 days & $\begin{array}{c}7 \\
(58.33 \%)\end{array}$ & $\begin{array}{c}5 \\
(41.66 \%)\end{array}$ & \\
\hline$>30$ days & $\begin{array}{c}3 \\
(50 \%)\end{array}$ & $\begin{array}{c}3 \\
(50.0 \%)\end{array}$ & \\
\hline \multicolumn{4}{|l|}{$\begin{array}{l}\text { Diabetes } \\
\text { mellitus }\end{array}$} \\
\hline Yes & $\begin{array}{c}16 \\
(44.44 \%)\end{array}$ & $\begin{array}{c}20 \\
(55.55 \%)\end{array}$ & 0.008 \\
\hline No & $\begin{array}{c}8 \\
(17.39 \%)\end{array}$ & $\begin{array}{c}38 \\
(82.6 \%) \\
\end{array}$ & \\
\hline \multicolumn{4}{|l|}{$\begin{array}{l}\text { Long term use } \\
\text { of steroids }\end{array}$} \\
\hline Yes & $\begin{array}{c}0 \\
(0.0 \%)\end{array}$ & $\begin{array}{c}1 \\
(100.0 \%)\end{array}$ & 0.517 \\
\hline No & $\begin{array}{c}24 \\
(29.62 \%)\end{array}$ & $\begin{array}{c}57 \\
(70.37 \%)\end{array}$ & \\
\hline \multicolumn{4}{|l|}{$\begin{array}{l}\text { On } \\
\text { chemotherapy } \\
\text { prior to } \\
\text { admission }\end{array}$} \\
\hline Yes & $\begin{array}{c}1 \\
(50 \%)\end{array}$ & $\begin{array}{c}1 \\
(50.0 \%)\end{array}$ & 0.514 \\
\hline No & $\begin{array}{c}23 \\
(28.75 \%)\end{array}$ & $\begin{array}{c}57 \\
(71.25 \%)\end{array}$ & \\
\hline \multicolumn{4}{|l|}{$\begin{array}{l}\text { Long-term } \\
\text { antibiotics }\end{array}$} \\
\hline Yes & $\begin{array}{c}10 \\
(66.67 \%)\end{array}$ & $\begin{array}{c}5 \\
(33.33 \%)\end{array}$ & 0.001 \\
\hline No & $\begin{array}{c}14 \\
(20.89 \%)\end{array}$ & $\begin{array}{c}53 \\
(79.11 \%)\end{array}$ & \\
\hline
\end{tabular}

*VAP - Ventilator Associated Pneumonia

When considering the knowledge levels regarding the hand hygiene, standard precautions, spill management and the hospital acquired infections separately, the percentages of the correct responses were $84.55 \%, 76.85 \%, 67.7 \%$ and $79.44 \%$ respectively. Hence nursing officers were least knowledgeable on the spill management. 
Table 3. Factors associated with hospital acquired Urinary Tract Infections

\begin{tabular}{|c|c|c|c|}
\hline $\begin{array}{l}\text { Associated } \\
\text { factors }\end{array}$ & $\begin{array}{c}\text { UTI } \\
\text { positive }\end{array}$ & $\begin{array}{c}\text { UTI } \\
\text { negative }\end{array}$ & p value \\
\hline \multicolumn{4}{|l|}{$\begin{array}{l}\text { Age } \\
\text { categories }\end{array}$} \\
\hline$<35$ years & $\begin{array}{c}1 \\
(3.71 \%)\end{array}$ & $\begin{array}{c}27 \\
(96.29 \%)\end{array}$ & 0.376 \\
\hline 35-64 years & $\begin{array}{c}7 \\
(11.30 \%)\end{array}$ & $\begin{array}{c}55 \\
(88.70 \%)\end{array}$ & \\
\hline$\geq 65$ years & $\begin{array}{c}3 \\
(15 \%) \\
\end{array}$ & $\begin{array}{c}17 \\
(85.0 \%)\end{array}$ & \\
\hline \multicolumn{4}{|l|}{$\begin{array}{l}\text { Duration of } \\
\text { stay in the } \\
\text { ICU }\end{array}$} \\
\hline 2-7 days & $\begin{array}{c}6 \\
(8.95 \%)\end{array}$ & $\begin{array}{c}61 \\
(91.05 \%)\end{array}$ & 0.764 \\
\hline 8-14 days & $\begin{array}{c}3 \\
(11.12 \%)\end{array}$ & $\begin{array}{c}24 \\
(88.88 \%)\end{array}$ & \\
\hline $15-30$ days & $\begin{array}{c}2 \\
(16.67 \%)\end{array}$ & $\begin{array}{c}10 \\
(83.33 \%)\end{array}$ & \\
\hline$>30$ days & $\begin{array}{c}0 \\
(0 \%)\end{array}$ & $\begin{array}{c}4 \\
(100.0 \%)\end{array}$ & \\
\hline \multicolumn{4}{|l|}{$\begin{array}{l}\text { Diabetes } \\
\text { mellitus }\end{array}$} \\
\hline Yes & $\begin{array}{c}4 \\
(10.82 \%)\end{array}$ & $\begin{array}{c}33 \\
(89.18 \%)\end{array}$ & 0.84 \\
\hline No & $\begin{array}{c}7 \\
(9.58 \%) \\
\end{array}$ & $\begin{array}{c}66 \\
(90.42 \%) \\
\end{array}$ & \\
\hline \multicolumn{4}{|l|}{$\begin{array}{l}\text { Long term } \\
\text { use of steroids } \\
\text { Yes }\end{array}$} \\
\hline No & $\begin{array}{c}0 \\
(0 \%) \\
11 \\
(10.28 \%)\end{array}$ & $\begin{array}{c}3 \\
(100.0 \%) \\
96 \\
(89.72 \%)\end{array}$ & 0.558 \\
\hline \multicolumn{4}{|l|}{$\begin{array}{l}\text { On } \\
\text { chemotherapy } \\
\text { prior to } \\
\text { admission } \\
\text { Yes }\end{array}$} \\
\hline Hes thestests & $\begin{array}{c}0 \\
(0 \%) \\
11 \\
(10.28 \%) \\
\end{array}$ & $\begin{array}{c}3 \\
(100.0 \%) \\
96 \\
(89.72 \%) \\
\end{array}$ & 0.558 \\
\hline \multicolumn{4}{|l|}{$\begin{array}{l}\text { Long-term } \\
\text { antibiotics }\end{array}$} \\
\hline $\begin{array}{l}\text { Yes } \\
\text { No }\end{array}$ & $\begin{array}{c}5 \\
(27.77 \%) \\
6 \\
(6.53 \%)\end{array}$ & $\begin{array}{c}13 \\
(72.23 \%) \\
86 \\
(93.47 \%)\end{array}$ & 0.006 \\
\hline
\end{tabular}

*UTI - Urinary Tract Infections

\section{Discussion}

This study consisted of two components. First component assessed the prevalence of Hospital Acquired Infections (HAIs) and their associated factors among the patients treated at the Intensive Care Units (ICUs) in the National Hospital of Sri Lanka (NHSL). The other component assessed the knowledge among the nursing officers regarding the precautions taken to minimize hospital acquired infections.

This was one of the few local studies conducted regarding the prevalence of HAIs in ICUs in
NHSL. According to our study, VAP was the most prevalent (29.3\%) hospital acquired infection in the ICUs. Only 5.5\% had hospital acquired BSIs. This is compatible with the study done by Wanigasuriya (1999) in the ICUs at the NHSL, which stated that lower respiratory tract infections occurred in $28.4 \%$, UTIs in $20.0 \%$ and infections of intravenous cannula site in $19.2 \%$ of patients admitted to ICUs[2].

Table 4. Factors associated with hospital acquired blood stream infections

\begin{tabular}{|c|c|c|c|}
\hline $\begin{array}{l}\text { Associated } \\
\text { factors }\end{array}$ & $\begin{array}{c}\text { Blood- } \\
\text { stream } \\
\text { infections } \\
\text { positive }\end{array}$ & $\begin{array}{c}\text { Blood- } \\
\text { stream } \\
\text { infections } \\
\text { negative }\end{array}$ & $\begin{array}{c}\mathbf{p} \\
\text { value }\end{array}$ \\
\hline \multicolumn{4}{|l|}{ Age categories } \\
\hline$<35$ years & $\begin{array}{c}0 \\
(0 \%)\end{array}$ & $\begin{array}{c}28 \\
(100.0 \%)\end{array}$ & 0.28 \\
\hline 35-64 years & $\begin{array}{c}4 \\
(6.45 \%)\end{array}$ & $\begin{array}{c}58 \\
(93.54 \%)\end{array}$ & \\
\hline$\geq 65$ years & $\begin{array}{c}2 \\
(10 \%)\end{array}$ & $\begin{array}{c}18 \\
(90.0 \%)\end{array}$ & \\
\hline \multicolumn{4}{|l|}{$\begin{array}{l}\text { Duration of stay } \\
\text { in the ICU }\end{array}$} \\
\hline 2-7 days & $\begin{array}{c}4 \\
(5.97 \%)\end{array}$ & $\begin{array}{c}63 \\
(94.02 \%)\end{array}$ & 0.89 \\
\hline 8-14 days & $\begin{array}{c}1 \\
(3.71 \%)\end{array}$ & $\begin{array}{c}26 \\
(96.29 \%)\end{array}$ & \\
\hline 15-30 days & $\begin{array}{c}1 \\
(8.33 \%)\end{array}$ & $\begin{array}{c}11 \\
(91.66 \%)\end{array}$ & \\
\hline$>30$ days & $\begin{array}{c}0 \\
(0 \%)\end{array}$ & $\begin{array}{c}4 \\
(100.0 \%)\end{array}$ & \\
\hline $\begin{array}{l}\text { Diabetes } \\
\text { mellitus } \\
\text { Yes } \\
\text { No }\end{array}$ & $\begin{array}{c}3 \\
(8.11 \%) \\
3 \\
(4.11 \%)\end{array}$ & $\begin{array}{c}34 \\
(91.89 \%) \\
70 \\
(95.89 \%)\end{array}$ & 0.38 \\
\hline \multicolumn{4}{|l|}{$\begin{array}{l}\text { Long term use of } \\
\text { steroids }\end{array}$} \\
\hline Yes & $\begin{array}{c}0 \\
(0 \%)\end{array}$ & $\begin{array}{c}3 \\
(100.0 \%)\end{array}$ & 0.67 \\
\hline No & $\begin{array}{c}6 \\
(5.61 \%)\end{array}$ & $\begin{array}{c}101 \\
(94.39 \%)\end{array}$ & \\
\hline $\begin{array}{l}\text { On } \\
\text { chemotherapy } \\
\text { prior to } \\
\text { admission } \\
\text { Yes } \\
\text { No }\end{array}$ & $\begin{array}{c}0 \\
(0 \%) \\
6 \\
(5.61 \%)\end{array}$ & $\begin{array}{c}3 \\
(100.0 \%) \\
101 \\
(94.39 \%)\end{array}$ & 0.67 \\
\hline \multicolumn{4}{|l|}{$\begin{array}{l}\text { Long-term } \\
\text { antibiotics }\end{array}$} \\
\hline Yes & $\begin{array}{c}2 \\
(11.12 \%)\end{array}$ & $\begin{array}{c}16 \\
(88.88 \%)\end{array}$ & 0.24 \\
\hline No & $\begin{array}{c}4 \\
(4.35 \%)\end{array}$ & $\begin{array}{c}88 \\
(95.65 \%)\end{array}$ & \\
\hline
\end{tabular}

Another study which had been conducted in 2014 also supports the fact that there is high prevalence of VAP in ICUs at NHSL[6]. The European prevalence of infection in intensive care (EPIC) study which was carried out to assess the prevalence of HAIs in Europe stated the most frequently reported HAIs in ICUs were VAP 
followed by hospital acquired UTIs and catheter associated BSIs[7]. The INICC (International Nosocomial Infection Control Consortium) surveillance study from January 2007 December 2012 conducted in 503 ICUs in Latin America, Asia, Africa and Europe also showed similar results[8].

In the study we carried out we observed that duration of stay, diabetes mellitus and long-term use of antibiotic had significant associations with VAP while only long-term use of antibiotics was found to be significantly associated with hospital acquired UTI. We couldn't identify any factors that were significantly associated with hospital acquired blood stream infections. According to an observational prospective study conducted in the ICUs of a University hospital in Turkey, diabetes mellitus, length of stay, use of steroids and antibiotics were found as the significant risk factors for nosocomial infections and only use of antibiotics was found to be the risk factor of UTIs[9]. Similarly, a prospective observational study conducted among 242 patients in ICUs in a public tertiary teaching hospital in India has reported that prior anti-microbial use and length of ICU stay to be statistically significant associated factors with nosocomial infections[10]. We did not find a significant association between use of steroids and HAIs. Lack of patients who were on long term steroids in our study population is a possibility.

As transmission based precautions have to be carried out by all the health care workers in the hospital specially by nursing officers, it is important for them to have satisfactory knowledge since they are responsible for assisting procedures like catheterization, cultures, lumbar punctures, surgeries, cannulation, blood drawing and administering injections etc. According to the assessment, majority of nursing officers had a moderate knowledge $(50 \%)$. When considering the different aspects of knowledge, the knowledge on hand hygiene $(84.5 \%)$ and hospital acquired infections $(79.4 \%)$ were adequate while the knowledge regarding the spill management needed improvement. Knowledge on hand hygiene was high, may be due to regular practice. Lack of knowledge on proper spill management may lead to an increase in HAIs.

A research which has been conducted among the final year medical \& nursing students at the University of Sri Jayawardenapura, regarding the knowledge, attitudes \& practices of hand hygiene has also revealed that majority (77\%) had moderate knowledge[11].
The limitations in our study were as follows. The findings cannot be generalized to other institutes as NHSL is a highly specialized institute with many facilities. The temporal associations could not be elicited for some factors because this was a cross sectional study. For the purpose of this study we had to depend on the microbiological and radiological investigations carried out by the hospital. Due to practical limitations we couldn't verify the standards of the investigations.

\section{Conclusions and recommendations}

It can be concluded that the most frequently detected hospital acquired infection among patients in ICUs in the NHSL was VAP, followed by hospital acquired UTI and hospital acquired blood stream infections. Length of ICU stay, diabetes mellitus and prior antimicrobial therapy were found to be significant risk factors associated with the acquisition of nosocomial infections.

Though adequate levels of knowledge on standard precautions was demonstrated, knowledge on transmission-based precautions including spill management was substandard among the ICU nurses.

Academic courses and conferences regarding hospital acquired infections should be conducted to all health care professionals working at the ICUs. Academic posters should be displayed at NHSL premises. The infection control unit at NHSL should be addressed regarding this issue on hospital acquired infections. We also recommend to hold training courses for the nursing staffs based on successful educational models. Finally, further studies to find more associations with hospital acquired infections are recommended.

\section{Acknowledgement}

Our research was carried as a part of our undergraduate curriculum under the supervision of the Department of Community Medicine, Faculty of Medicine, University of Colombo.

We would also like to thank Dr. Anil Jasinghe, Director, NHSL, Sri Lanka and the medical staff in ICUs in NHSL.

\section{References}

1. Bannister BA, Gillespie SH, Jones J. Infection: microbiology and management 
$3^{\text {rd }}$ ed.:BlackwellPublishing Ltd.2006:443459.

2. Wanigasuriya JKP. Nosocomial Infections in the intensive care units at the National Hospital of Sri Lanka, 1999. Available from: http://dl.nsf.ac.lk/handle/1/19017

3. Guidelines for the prevention of intravascular catheter-related infections. 2011. Centers for disease control and prevention.

4. Tavolacci MP, Ladner J, Bailly L et al. Prevention of nosocomial infection and standard precautions: knowledge and source of information among healthcare students. Infect Control Hosp Epidemiol. $2008 \mathrm{Jul} ; 29(7): 642-7$.

5. Ojulong J, Mitonga $\mathrm{KH}$, Iipinge $\mathrm{SN}$. Knowledge and attitudes of infection prevention and control among health sciences students at University of Namibia. Afr Health Sci. 2013 Dec;13(4):1071-8.

6. Nakkawita WMID, Patabendige CGUA. Incidence of ventilator associated pneumonia in three intensive care units at National Hospital of Sri Lanka, Colombo. The Bulletin of the Sri Lanka College of Microbiologists; 2015;13(1):9 - 10.

7. Vincent JL. The prevalence of nosocomial infection in intensive care units in Europe. Results of the European Prevalence of Infection in Intensive Care (EPIC) Study. EPIC International Advisory Committee]. Vol. 274, JAMA: The Journal of the American Medical Association 1995.p.639-44.

8. Rosenthal VD et al. International Nosocomial Infection Control Consortium report, Data summary of 43 countries for 2007-20012, Device associated module. Am J Infect Control. 2014 Sep;42(9):94256.

9. Ozer B, Akkurt BCO, Duran $\mathrm{N}$ et al. Evaluation of nosocomial infections and risk factors in critically ill patients. Vol. 17, Medical Science Monitor. 2011. p. PH1722. Available from: http://dx.doi.org/10.12659/msm.881434

10. Dasgupta S, Das S, Chawan NS et al. Nosocomial infections in the intensive care unit: Incidence, risk factors, outcome and associated pathogens in a public tertiary teaching hospital of Eastern India. Indian $J$ Crit Care Med. 2015 Jan;19(1):14-20.

11. Ariyarathne MHJD, Gunasekara TDCP, Weerasekara MM et al. Knowledge, attitudes and practices of hand hygiene among final year medical and nursing students at the University of Sri Jayewardenepura. Vol. 3, Sri Lankan
Journal of Infectious Diseases. 2013. p. 15. Available from:

http://dx.doi.org/10.4038/sljid.vguidelines 